\title{
Motivational Values of Ukrainian Students and the Use of Distance Learning Form in Legal Education
}

\author{
Sergey Kivalov*, Liubov Bila-Tiunova \\ Department of Administrative and Financial Law, National University Odessa Academy of Law, Ukraine
}

Received October 24, 2019; Revised December 5, 2019; Accepted December 11, 2019

Copyright $\mathrm{C} 2020$ by authors, all rights reserved. Authors agree that this article remains permanently open access under the terms of the Creative Commons Attribution License 4.0 International License

\begin{abstract}
In order to implement new national curriculums in the field of higher education in Ukraine, it is necessary to use the open educational forms as one of the sustainable development conditions. Therefore, the authors used a correlated analysis, Kolmogorov-Smirnov test, F-test, and Pearson's chi-squared test in order to examine the Ukrainian students' motivation towards the education according to the theory of internal motivation. The present study was based on the experiment conducted in two separate universities in Ukraine. Participants of the study were students of higher education facilities, who studied on the specialty "Law". In total, 130 students were offered to take part in the experiment and only 104 students agreed on the participation. Therefore, they completed the written consent, and data were collected by survey information. The losses were due to the absence of the students or lack of the written consents during the experiment. Thus, they voluntarily participated in the study and answered the blank anonymously. Moreover, the universe rate was within the confidence interval. In addition, authors stated that the choice between traditional and ICT (Information and Communication Technologies) based educational approaches had a serious impact on the distribution of students' motivational values. In fact, students showed higher efficiency index while studying the law with the help of distance learning. However, participants did not believe that using the distance learning form would not help them to study well and pass their exams on "4" and "5". Therefore, it is established that the whole opportunity value to pay attention to the problems interesting for students is the sole harbinger for the thesis that the study of law with the help of the distance learning form makes their education qualitative. Thus, it is argued that the Ukrainian students are motivated to study law with the help of ICT, but the value distribution is different according to gender roles. For example, males may have more benefit from the use of ICT whereas females need another point of interest to use the distance learning form to study law.
\end{abstract}

Keywords Distance Learning, Higher Education, ICT, Internal Motivation Theory, Law, Ukraine

\section{Introduction}

\subsection{Background and Research Questions}

Modern society is characterized by the general use of modern technologies in all fields of activity. Therefore, the education sector, which undergoes informatization process under mass communication impact, is not an exception. In fact, it provides methodology, technology, practice of research, educational, methodological, and training methods, creation of software and technological developments, and optimal usage oriented at the realization of information and communication technologies' opportunities for the purposeful organized process of education.

Of course, scientists, teachers and managers in the education sector confirmed the role of the distance learning form in studying the law (Wu, 2015; Lucky, Branham \& Atchison, 2019; Muilenburg \& Berge, 2005). Therefore, practical scientific activity may be unfolded using distance courses that are significant. However, implementing new national education programs for bachelors of juridical specialties in Ukraine means that the use of information and communication technologies is a crucial part of legal education. Thus, it is thought that bachelors will have an opportunity to study using alternative learning methods.

Moreover, socio-economic conditions which happened in the East of Ukraine influenced the search for options of peoples' attraction. One of the attractive options was distance learning. Therefore, researchers conducted all-Ukrainian experiment on the "Organizatsiya professionalnogo obucheniya uchasheisya molodezhy i 
vzroslych prozhyvaushich na vremenno okupirovannoi territorii i $\mathrm{v}$ naselennych punktach i na linii soprikosnoveniya $\mathrm{s}$ ispolzovaniyem technologi distantsyonnogo obucheniya" (Nakaz Ministerstva osvity ta nauky vid $10.10 .2018,2018)$. Outputs obtained by the experiment showed the population attraction to technical-vocational education with the help of distance learning. However, in the context of the experiment, the distance and full-day learning forms were not compared because the last learning form was impossible for some reasons.

Data obtained by international scientific studies indicated that the impact of the distant learning forms on the use of interactive technologies depends on the established criteria. That's why the research aimed at providing deeper understanding of the problem with less data can be as important as large-scale surveys. Thus, this study aimed to study the opportunity of the use of distance learning in legal education and whether it has a similar or different impact on the Ukrainian students' motivation. Therefore, we obtained data from 104 Ukrainian students. The results implied the novelty of the study. Here, questions of the study are presented:

1. Does the motivational value of the third-year students studying law in a full-day form differ from the value of students studying in the distance learning form?

2. Do males and females have the same motivational value for the study of law in a full-day form in comparison with the distance learning form?

3. How is the motivational value of the third-year students compared to their perspective of the opportunities of studying the law with the help of the distance education methods?

We used education motivation theory to examine the first and second questions (Badmayeva, 2004). The last question dealt with the questionnaire part analysis, which asked the respondents whether the law was easier to understand if it was being studied with the help of the distance learning form.

\subsection{Summary of Higher Legal Education of Ukraine}

It is notable that the unified normative-legal act identifying the features of higher legal education is now absent in Ukraine. In fact, Verkhovna Rada of Ukraine defined that fundamental principles of higher education laid out on legal education. Actually, the learning forms concern the art. 49 of the Law of Ukraine "O Vyshem obrazovanii", stating that education in higher education facilities is carried out in a full-day (day and evening) and distance learning courses. Moreover, they can be mixed (Pro vyshu osvitu, 2014). Of course, recognition of the distance education as an analogue to the distance learning form is an arguable statement, but the mixed learning forms implementation opportunity was important for this research. According to the distance learning form, it is understood as an individualized implementation process of people's knowledge, skills and cognitive activity, which happens through cooperation of the remote participants' education process in a specialized field. Actually, it functions on the ground of modern psychoeducational and information and communication technologies (Pro dystantsiine navchannia, 2013).

The aims of the distance learning form implementation into the education process include provision of an organic combination in the education process of educational, scientific, and innovative activity, creation of the necessary conditions for realization of the participants' skills and talents, diffusion of knowledge among people, increase of both educational and cultural skills at national level, establishment of the overseas communication, and implementation of international activities in education, science, sport and culture sectors, which are generalized in the national education program (Pro osvitu, 2017).

However, recent studies on the information and communication technologies in higher legal education have shown that the implementation practice of online-workshop (webinar) technologies', which demonstrates comparative tables, presentations, reels, and so on, is a reasonable task. In fact, with the help of the internet-technologies, the online-workshop kept the main feature of the workshop, namely their interactivity with the speakers, listeners, and those who work online modeling function. To do so, significant consolidated actions of chairs, informational centers, laboratories, and libraries are important for its filling with the qualitative problem-oriented resources as well as for knowledge acquisition. For instance, the use of education platforms, for example, Moodle, through which the teacher has an opportunity to offer its works and organize the teaching control, would be acceptable. If the teacher is motivated to use information and communication technologies, the teaching materials are changed for virtual manipulators. However, it should be noted that only a small percent of Ukrainian teachers passed the programming courses. Thus, the use of information and communication technologies in legal education depends on the teachers' option as to how to master new technologies.

\subsection{Theoretical Framework and a Review of Literature}

One of the main reasons for the implementation of the distance learning form in legal education is to provide students with a broader access to education in comparison with the traditional education methods as far as students may start their own education from any place and at any time. Moreover, the students are provided with an opportunity to combine the study. In general, the distance learning form is a universal, synthetic, integral, and humanistic form of education, which creates conditions 
for the participants' cooperation with the help of modern psychoeducational and information and communication technologies. In this research, the distance learning form included digital instruments and programs such as computers, tablets, online-instruments, education provisions, and programs. Notably, online-lessons, elaborated tests, presentations and tables are the educational provisions used by teachers during the education process and those materials that are used by the higher education candidates during the independent work.

With regard to the national documents concerning the distance learning form implementation in higher legal education, a clear list of distance learning forms is absent, which could be attributed to a high speed of change and development of information and communication technologies.

\subsection{Theory of Intrinsic Motivation}

Internal motivation theory was considered as the theoretical framework of the study, according to which, the students' achievement in education is related to the necessity to understand the world through active behavior (including the independent work). Such behavior is understood as a constant activity stream with the effective cooperation of the environmental components (education environment). In fact, R. Woodworth (1950) introduced the theory of inner motivation in 1918 when behavioral approaches stopped to comply with the corresponding motivation components.

In the context of inner motivation, the notion "competence" means that when the students' activity does not get any visible conformation, it has one aim, namely, the people competence behavior which is achieved by the "motivation through the feeling of efficiency" (almost equivalent to the concept of "inner motivation" (White, 1959). Thus, the inner motivation is the most natural one which leads to the best result of any activity. The same hypothesis was developed by M. Zaccone and M. Pedrini (2019). It is clear that real education process is accompanied by immediate inner motivation factors, according to which, the education purpose is defined. These factors include the students' orientation at marks, prestige, active life, and so forth.

In addition, the value indexes are related to the conscious perception of excellence in the ability of the distance learning form for studying law, which requires understanding the motivational determinants in a full-day form and the distance learning form. The questionnaire items for this research also concerned the impact of motivational factors on the development of the students' mental abilities (Badmayeva, 2004).

\subsection{Previous Research}

Review of the literature confirmed excellent conclusions about the impact of the distance learning form on the students' motivation and the use of information and communication technologies in this field.

According to I.C. Mbaeze, U. Elochukwu, and A. Choima's (2010) thesis, there will not be statistically important dependency between the use of computers and education by students. They examined the impact of information and communication technologies on the students' achievements. Their study included 120 participants who were selected by random technique, that is, (Yes / No). The blank dealt with the increased opportunity of the use of information and communication technologies for students' education results. The answer was registered like Yes / No with the norm of 19.5. The second part of the blank was concentrated on the students' skills and experiences in using computers and internet services. It was found that there were not statistically important mark - X2 $=2,06$ and the critical value of $F$ 3,83 with the significance level of 0,05 between the information and communication technologies and the students' education efficiency. Therefore, we discussed on the conclusion, which required verification by determining the students' motivation level to education, especially of those studying with the help of the distance learning forms.

In this regard, M. Radovan (2011) detected possible relationships between the self-regulating education measurement and students' success according to the program of the distance learning form. The sampling was taken of 319 students who filled the "motivational strategies of the blank study" whereas the results were compared with the number of the exams passed, the frequency of the exam revision, and the average mark. The results showed the importance of the motivation factors such as the inner-oriented and the self-efficiency aims on one hand and the strategy of the efforts of regulations on the other hand.

Here, it is noteworthy to refer to the conclusions made by A.M. Ali, A. Sahbi and A. Ayari (2012) during their study of the effect of the use of technology on the students' motivation. In fact, authors aimed to improve the students' motivation because the training results depend on the motivation level. Therefore, a thesis was proposed that the technology may be a serious instrument for the students' attraction to the training process. Notably, this instrument should be used moderately. Teachers should keep control on it during the process of a task making with the help of information technologies. However, experimental data was not confirmed. A similar research was carried out by M. Hartnett, G. Alison, and J. Dron (2011). These authors pointed out that constant communication between students and teachers should take place to allow the first to discuss the question open and fair, whereas practice teachers should control and react to the situational factors which can undermine the students' motivation.

In general, there are no studies conducted on the 
students' motivation together with the right to use the distance learning form. For example, J. Francis (2017) examined the effect of the information and communication technologies implementation on the New England Charter School's 7-12 pupils. The author concluded that those pupils who can have access to the program in an individual way are delighted and more motivated. However, S.A. El-Seoud et al.'s (2014) study could be useful in the field. These researchers investigated the education level in the internet versus traditional training methods, differences with e-learning according to the year, difference with e-learning according to the chair, differences in marks during the exams, and the teachers' role in the whole process. Many researches showed that the effective use of e-learning contributed to the increased motivation of pupils. Nevertheless, integration of information and communication technologies into the training process depends on the personal participants' motivation. To allow students to maximize their potential, they have to maintain their digital training. However, many experiments showed that the students had to increase their level of technological and communicative skills in order to have a chance to use the opportunities the e-learning would provide. In addition, the absence of confidence and experience of using technologies may be an additional obstacle for students and teachers. During the process of e-learning, the students work independently, whereas for some of them, it is difficult to understand it without personal contact with teachers and other students. All these factors indicate that these students will not be able to take part in the process of e-learning. Thus, for the proper progress and successful use of all the instruments, some students should have corresponding equipment and skills.

Finally, literature review showed that the most probable hypothesis is that the use of the distance learning form helps to expand accessibility to higher education and the level of motivation but at the same time not lower than while studying in a full-day form.

\section{Materials and Methods}

\subsection{Data}

First of all, we elaborated the research questionnaire in order to collect data about students' motivation to study law with the help of the full-day form methods and information and communication distance learning forms methods. Therefore, the questionnaire consisted of two parts: the blank for identifying the students' inner motivation level and the blank for the effective use of the distance learning form.

The blank for identification of the students' inner motivation level included 34 statements concerning the study of law through the methods inherent in the full-day form (lecture and practical training) and similar statements concerning the study of law with the help of information and communication technologies inherent in the distance learning form (See Appendix). Students had to answer on a 1-5 scale to the statements (where 1 mark means the lowest point and 5 means the highest one) at every point. The questionnaire statement corresponds to the detailed points, that is, communicative, prestige, learning, creative self-realization, social, professional, and avoidance ones. Thus, the higher the mark for the statement corresponds to the points, the better it is.

The blank for the efficient use of the distance learning form consisted of 12 statements aimed at establishing whether the student thinks that the study of law is easier (for example, "I know that I will be able to study it faster" or "I understand that I will be able to remember it faster".) with the help of the distance learning form. Students were offered to answer with Yes / No forms.

According to the blank point, it was found out that they were close to the maximum and students had the opportunity to concentrate on the answers.

\subsection{Participants and Data Collection}

This poll was carried out in two different Universities of Ukraine. Therefore, students completed the written consent, and data were collected by survey information. The research purpose was verbally explained during the tutorial which lasted for 1 hour and 20 minutes. During this interval, the statements of the distance learning form were explained and specified to the participants. Then, the students underwent the briefing as to how to fill the blanks.

Participants of the study were the students of higher education facilities on the specialty of "the Law". In general, 130 students were offered to take part in the poll, and among them 104 students voluntarily participated in the study. The losses were due to the absence of the letter of consent or the students' absence during the poll. Thus, the general complex rate was within the confidence interval. Participants' answers were kept anonymously. In addition, a male-female sign was provided for further gender research on students' motivation.

According to the teachers interview, the distance learning form was used to study subjects such as "the Administrative law" and "the Public service in Ukraine". Therefore, the planned and available sources in the internet materials, competence tasks, and test questions were used to study separate subjects. In addition, meetings were arranged for those students who needed the use of video. Of course, teachers and students had the opportunity for similar reflection. Most often, the students worked on the subjects with the possibility of being studied via methods inherent in the distance learning form independently.

Based on the findings, the students had experience of 
using telecommunication methods while studying the law, which increased the validity of the data collected. During the data collection, there were no cases implying doubts in the reliability of the students' answers.

\subsection{Analyses}

SPSS was used to analyze the data. Moreover, we calculated the standard descriptive measures and examined distribution normality using the Kolmogorov-Smirnov test. In addition, we used the distribution-free test to compare data and applied Pearson's chi-squared test and F-test in order to examine the efficiency of the implementation of the distance learning form.

\section{Results}

We analyzed the result of the variables in order to determine the significance of the data collected. Figure 1 shows the normality of data distribution using Kolmogorov-Smirnov Test. The asymptotic value is lower than 0.05 , meaning that the distribution differs from the normal one and we should use the distribution-free test for data comparison.

Since the data in groups is nominative, we used Pearson's chi-squared test, which allows comparing data distribution measured in the nominative scale. Therefore, it shows the frequency of the occurrence of every point in the combined table whereas the asymptotic value is shown in the Pearson's chi-squared test table. The bar graph was also depicted based on the data obtained.

Figure 2 shows answers to the first question. According to the gender's role, there is a small difference between the points to education in the distance learning form and in a full-day form $(p>0.05)$. The significance level is 0.574 that it is more than 0.05 , meaning that there are no statistical differences between the groups. As is shown, the most common points in the full-day form are communicative and teaching factors. However, professional and social points spread in the distance learning form.

The average differences in Figure 2 can be generalized by the fact that the Ukrainian students have special perspective of the use of ICT in the study of law but they certainly do not oppose it.

\begin{tabular}{|c|c|c|c|c|}
\hline Normality of data distribution & $\begin{array}{c}\text { Male (the full } \\
\text { day form) }\end{array}$ & $\begin{array}{c}\text { Female (the full } \\
\text { day form) }\end{array}$ & $\begin{array}{c}\text { Male (the distance } \\
\text { learning form) }\end{array}$ & $\begin{array}{c}\text { Female (the distance } \\
\text { learning form) }\end{array}$ \\
\hline $\mathrm{N}$ & 49 & 55 & 49 & 55 \\
Normal Parametrs ${ }^{\mathrm{a}}{ }^{\mathrm{b}}$ Mean & 4,1224 & 4,4000 & 3,5510 & 4,4355 \\
Std Deviation & 2,17594 & 1,95884 & 2,21793 & 2,12758 \\
Most Extreme Differences Absolute & 194 & 175 & 186 & 163 \\
Positive & 121 & 145 & 186 & -163 \\
Negative & -194 & -175 & -171 & 163 \\
Test Statistic & 194 & 175 & 186 & $001^{\mathrm{c}}$ \\
Asymp. Sig (2-tailed) & $000^{\mathrm{c}}$ & $000^{\mathrm{c}}$ & $000^{\mathrm{c}}$ & \\
\hline
\end{tabular}

a - Test distribution is Normal

$\mathrm{b}$ - Calculated from data

c - Lilliefors Significance Correction

Figure 1. The normality of data distribution with the Kolmogorov-Smirnov test 


\begin{tabular}{|c|c|c|c|c|c|c|}
\hline \multirow{4}{*}{ Learning form points } & \multicolumn{6}{|c|}{ Cases } \\
\hline & \multicolumn{2}{|c|}{ Valid } & \multicolumn{2}{|c|}{ Missing } & \multicolumn{2}{|c|}{ Total } \\
\hline & $\mathrm{N}$ & Percent & $\mathrm{N}$ & Percent & $\mathrm{N}$ & Percent \\
\hline & 208 & $100 \%$ & 0 & $0,0 \%$ & 208 & $100 \%$ \\
\hline
\end{tabular}

\begin{tabular}{|c|c|c|c|c|c|c|c|}
\hline \multirow{2}{*}{ Learning form } & \multicolumn{7}{|c|}{ Points } \\
\cline { 2 - 8 } & $\begin{array}{c}\text { Professional } \\
\text { points }\end{array}$ & $\begin{array}{c}\text { Avoidance } \\
\text { points }\end{array}$ & $\begin{array}{c}\text { Prestige } \\
\text { points }\end{array}$ & $\begin{array}{c}\text { Communicative } \\
\text { points }\end{array}$ & $\begin{array}{c}\text { Creative } \\
\text { self-realization points }\end{array}$ & $\begin{array}{c}\text { Learning } \\
\text { points }\end{array}$ & $\begin{array}{c}\text { Social } \\
\text { points }\end{array}$ \\
\hline The full-day & 16 & 7 & 13 & 24 & 4 & 21 & 19 \\
The distance & 20 & 12 & 16 & 16 & 4 & 15 & 21 \\
Total & 36 & 19 & 29 & 40 & 8 & 36 & 40 \\
\hline
\end{tabular}

\begin{tabular}{|c|c|c|c|}
\hline Chi-Square Test & Value & df & Asymptotic Significance (2-sided) \\
\hline Pearson Chi-Square & $4,771^{\text {a }}$ & 6 & 0,574 \\
Likelihood Ratio & 4,803 & 6 & 0,560 \\
Liner-by-liner Association & 1,020 & 1 & 0,313 \\
N of Valid Cases & 208 & & \\
\hline
\end{tabular}

a -2 cells $(14,3 \%$ have expected countless than 5 . The minimum expected count is 4,00 .

\section{Bar Chart}

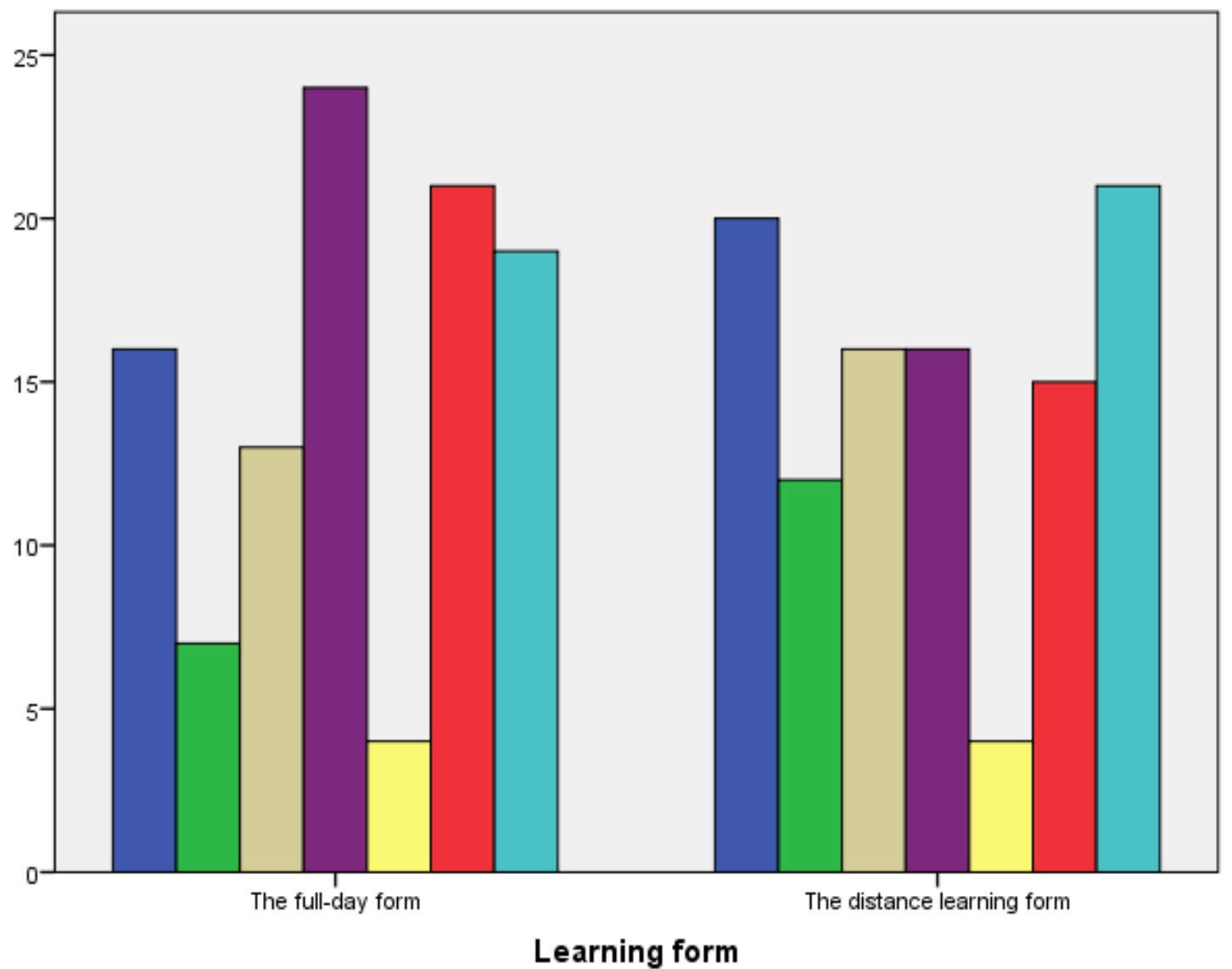

Figure 2. Correlation of the students' points to the education on the full-day form and the distance learning form 


\begin{tabular}{|c|c|c|c|c|c|c|c|}
\hline \multirow{2}{*}{ Learning form } & \multicolumn{7}{|c|}{ Points } \\
\cline { 2 - 8 } & $\begin{array}{c}\text { Professional } \\
\text { points }\end{array}$ & $\begin{array}{c}\text { Avoidance } \\
\text { points }\end{array}$ & $\begin{array}{c}\text { Prestige } \\
\text { points }\end{array}$ & $\begin{array}{c}\text { Communicative } \\
\text { points }\end{array}$ & $\begin{array}{c}\text { Creative self-realization } \\
\text { points }\end{array}$ & $\begin{array}{c}\text { Learning } \\
\text { points }\end{array}$ & $\begin{array}{c}\text { Social } \\
\text { points }\end{array}$ \\
\hline The full-day & 9 & 5 & 5 & 10 & 1 & 10 & 9 \\
The distance & 12 & 9 & 6 & 6 & 1 & 8 & 7 \\
Total & 21 & 14 & 11 & 16 & 2 & 18 & 16 \\
\hline
\end{tabular}

\begin{tabular}{|c|c|c|c|}
\hline Chi-Square Test & Value & df & Asymptotic Significance (2-sided) \\
\hline Pearson Chi-Square & $3,135^{\text {a }}$ & 6 & 0,792 \\
Likelihood Ratio & 3,164 & 6 & 0,788 \\
Liner-by-liner Association & 1,646 & 1 & 0,119 \\
N of Valid Cases & 98 & & \\
\hline
\end{tabular}

a -2 cells $(14,3 \%$ have expected countless than 5 . The minimum expected count is 1,00

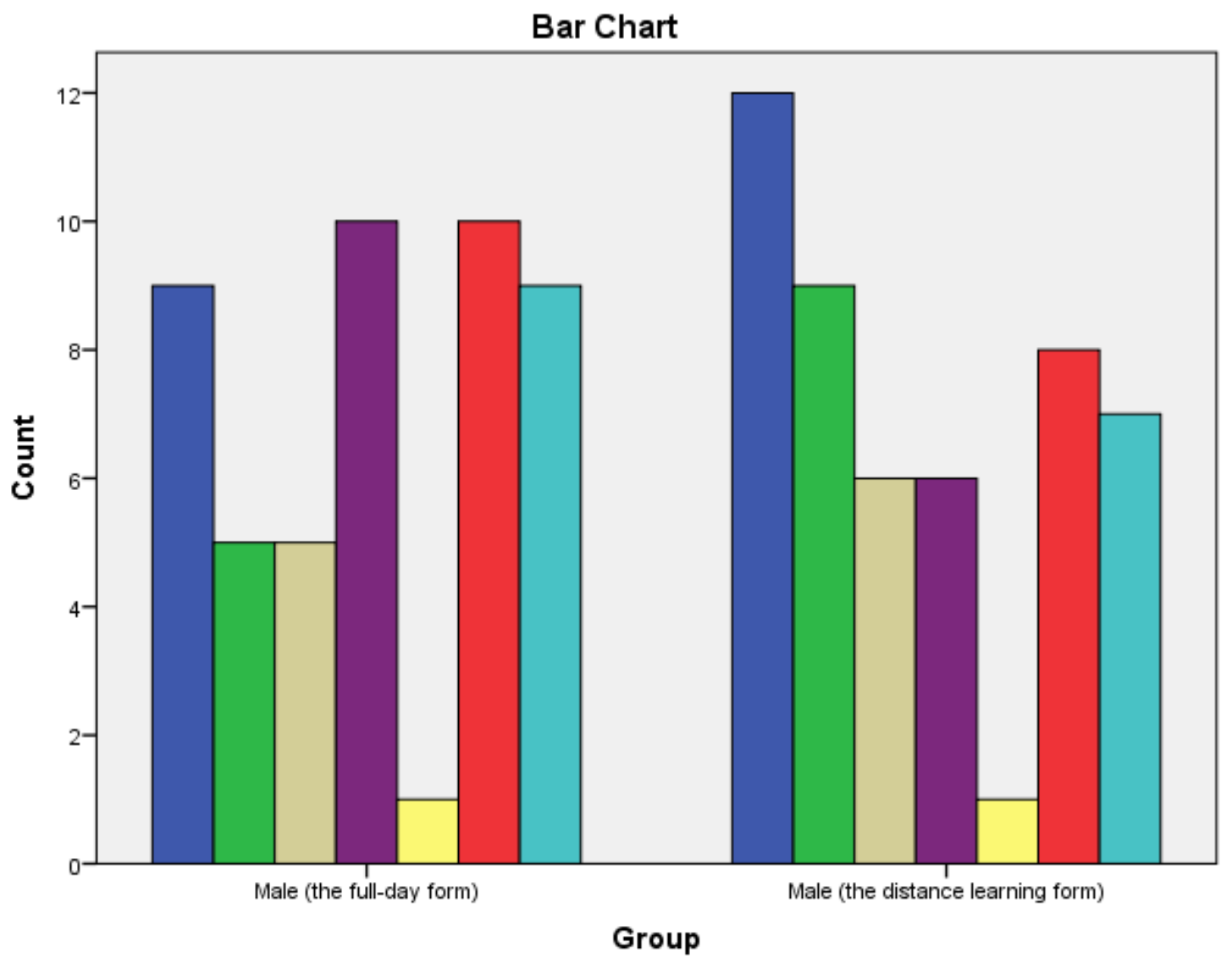

Figure 3. The males' points on the full-day form and the distance learning form

To examine the first question, we investigated the value distribution features according to the students' points. However, we conducted an analysis to examine the last question, which showed that gender interaction did not vary in each linear model ( $\mathrm{p}>0.05)$. According to Figure 3 , males showed lower prestige and creative self-realization points regardless of the training form. Nevertheless, professional and avoidance points were more common in the males using the distance learning form.

As is seen, the level of significance is 0,792 that is higher than 0.05 , meaning that there is no difference between the groups. Thus, it could be concluded that there was no difference between the males' points, who studied in the full-day form, and those studying in the distance learning form $(\mathrm{p}>0,05)$.

Figure 4 indicates that the females' social points are higher while studying in the distance learning form than in the full-day form. In fact, they have lower learning points while studying in the distance learning form. It is interesting that the average difference for inner motivation shown in Figures 3 and 4 is positive for the use of the distance learning form. However, the difference is not probably significant, but it could be interpreted that the use of the distance learning form may increase the interest in the study of law. 


\begin{tabular}{|c|c|c|c|c|c|c|c|}
\hline \multirow{2}{*}{$\begin{array}{c}\text { Learning } \\
\text { form }\end{array}$} & \multicolumn{7}{|c|}{ Points } \\
\cline { 2 - 8 } & $\begin{array}{c}\text { Professional } \\
\text { points }\end{array}$ & $\begin{array}{c}\text { Avoidance } \\
\text { points }\end{array}$ & $\begin{array}{c}\text { Prestige } \\
\text { points }\end{array}$ & $\begin{array}{c}\text { Communicative } \\
\text { points }\end{array}$ & $\begin{array}{c}\text { Creative self-realization } \\
\text { points }\end{array}$ & $\begin{array}{c}\text { Learning } \\
\text { points }\end{array}$ & $\begin{array}{c}\text { Social } \\
\text { points }\end{array}$ \\
\hline $\begin{array}{c}\text { The full-day } \\
\text { The distance }\end{array}$ & 7 & 2 & 8 & 14 & 3 & 11 & 10 \\
Total & 8 & 3 & 10 & 10 & 3 & 7 & 14 \\
\hline
\end{tabular}

\begin{tabular}{|c|c|c|c|}
\hline Chi-Square Test & Value & df & $\begin{array}{c}\text { Asymptotic Significance } \\
(2 \text {-sided })\end{array}$ \\
\hline Pearson Chi-Square & $2,711^{\text {a }}$ & 6 & 0,844 \\
Likelihood Ratio & 2,727 & 6 & 0,842 \\
Liner-by-liner Association & 0,020 & 1 & 0,888 \\
N of Valid Cases & 110 & & \\
\hline
\end{tabular}

a -4 cells $(28,6 \%$ have expected countless than 5 . The minimum expected count is 2,50

\section{Bar Chart}

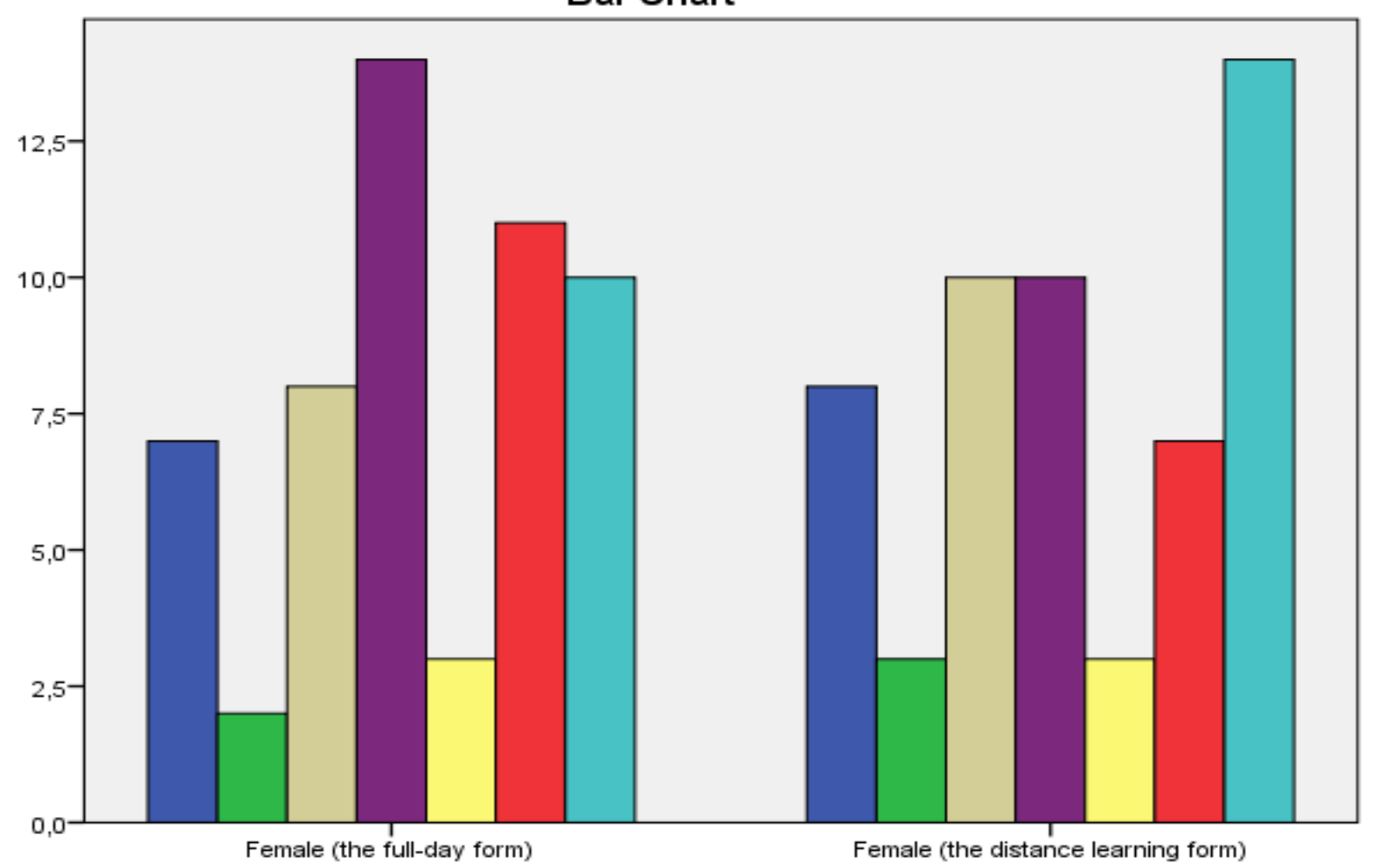

Figure 4. The females' points on the full-day form and the distance learning form

As shown in the chart, the level of significance is 0,844 which is higher than 0.05 , meaning that there is no difference between the groups. Thus, the data indicated that the females' points, who studied in the full-day form, did not differ from the males' points, who studied in the distance learning form $(\mathrm{p}>0,05)$. 


\begin{tabular}{|c|c|c|c|c|c|c|c|}
\hline \multirow{2}{*}{$\begin{array}{c}\text { Distance learning } \\
\text { form points }\end{array}$} & $\begin{array}{c}\text { Professional } \\
\text { points }\end{array}$ & $\begin{array}{c}\text { Avoidance } \\
\text { points }\end{array}$ & $\begin{array}{c}\text { Prestige } \\
\text { points }\end{array}$ & $\begin{array}{c}\text { Communicative } \\
\text { points }\end{array}$ & $\begin{array}{c}\text { Creative } \\
\text { self-realization points }\end{array}$ & $\begin{array}{c}\text { Learning } \\
\text { points }\end{array}$ & $\begin{array}{c}\text { Social } \\
\text { points }\end{array}$ \\
\hline The male & 12 & 9 & 6 & 6 & 1 & 9 & 7 \\
The female & 8 & 3 & 10 & 10 & 3 & 7 & 14 \\
Total & 20 & 12 & 16 & 16 & 4 & 16 & 21 \\
\hline
\end{tabular}

\begin{tabular}{|c|c|c|c|}
\hline Chi-Square Test & Value & df & Asymptotic Significance (2-sided) \\
\hline Pearson Chi-Square & $8,883^{\mathrm{a}}$ & 6 & 0,180 \\
Likelihood Ratio & 9,112 & 6 & 0,167 \\
Liner-by-liner Association & 3,390 & 1 & 0,066 \\
N of Valid Cases & 104 & & \\
\hline
\end{tabular}

a -2 cells $(14,3 \%$ have expected countless than 5 . The minimum expected count is 1,88

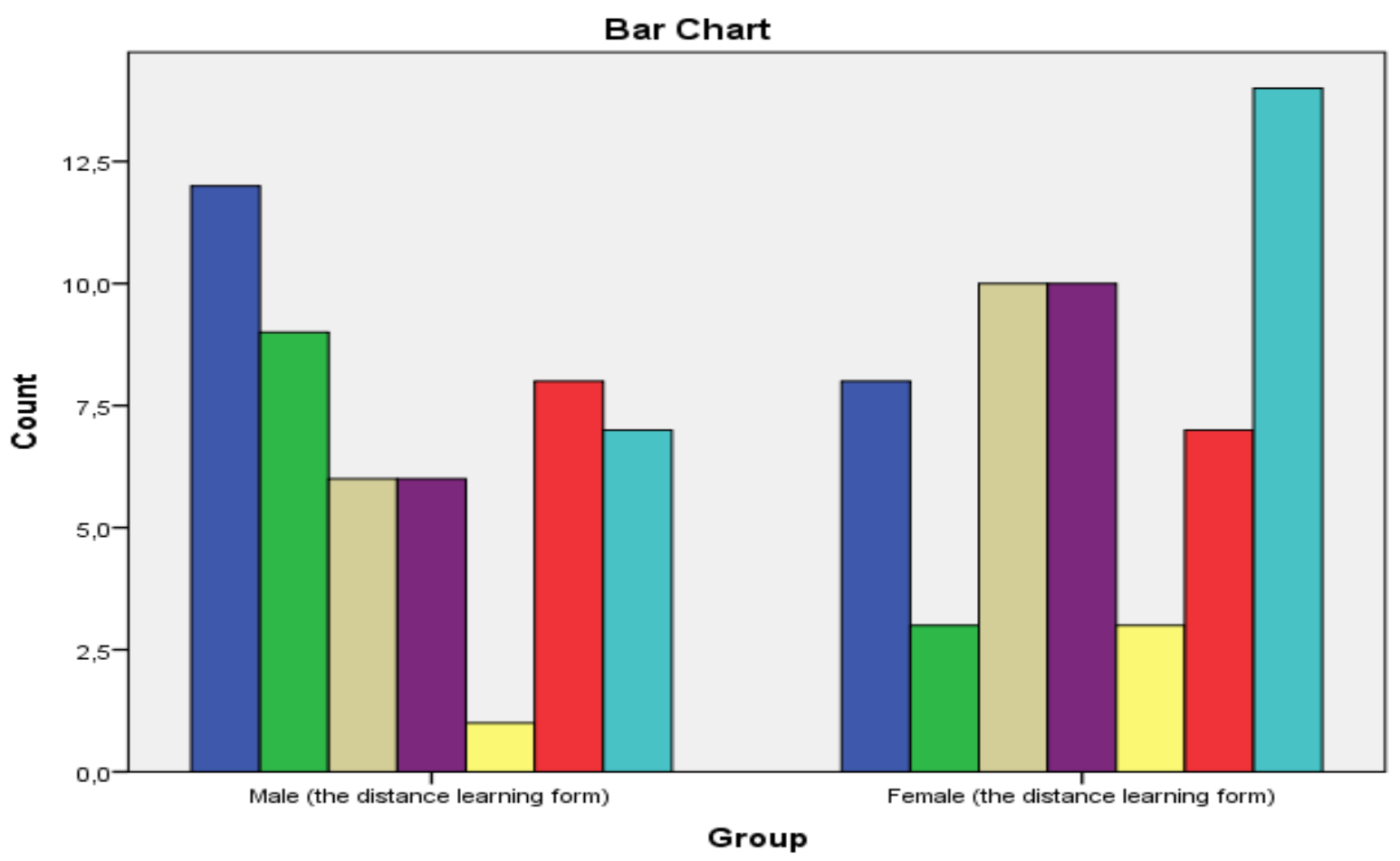

Figure 5. The males and females education points correlation to the distance learning form

As is seen, the level of significance is 0.18 that is higher than 0.05 , meaning that there is no difference between the groups. Thus, one could conclude that the males' points, who studied in the distance learning form, did not differ from the females' ones, who studied in the distance learning form ( $\mathrm{p}>0.05)$.

To answer the third question of the study, we used F-test. Figure 6 shows the answering results of the Ukrainian students on every question. 


\begin{tabular}{|c|c|c|c|}
\hline \multirow{2}{*}{ Answers to the question } & \multicolumn{2}{|c|}{ Group } & \multirow{2}{*}{ Total } \\
\cline { 2 - 4 } & Empirical distribution & Uniform distribution & \\
\hline No & 46 & 52 & 98 \\
Yes & 58 & 52 & 110 \\
\hline
\end{tabular}

Symmetric measures

\begin{tabular}{|c|c|c|}
\hline Nominal by nominal & Value & Approximate significance \\
\hline Phi &,- 058 &, 405 \\
Cramer's V &, 058 &, 405 \\
\hline
\end{tabular}

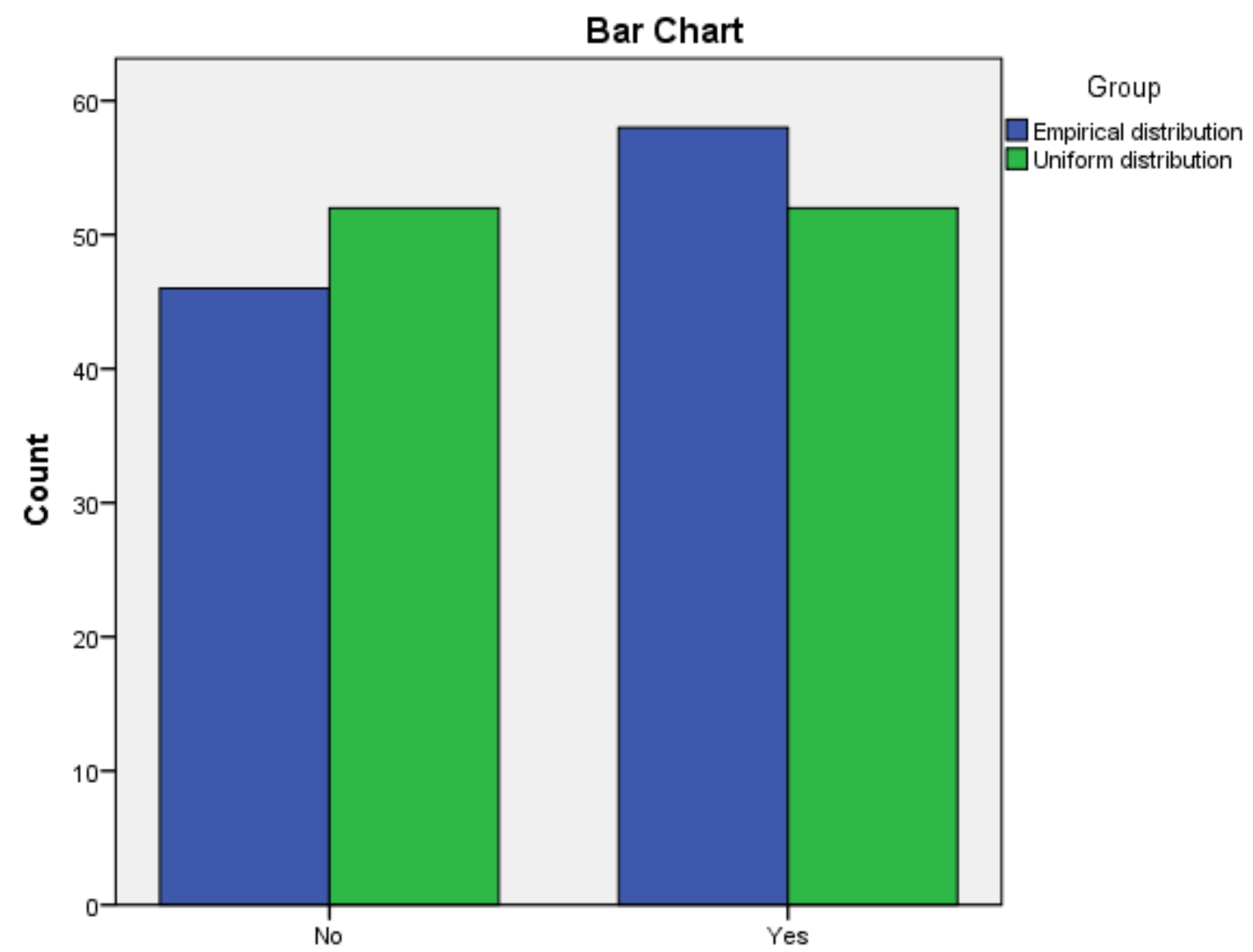

Figure 6. Answers to the question "I know that I will be able to study it faster with the help of ICT" 


\begin{tabular}{|c|c|c|c|}
\hline \multirow{2}{*}{ Answers to the question } & \multicolumn{2}{|c|}{ Group } & \multirow{2}{*}{ Total } \\
\cline { 2 - 4 } & Empirical distribution & Uniform distribution & \\
\hline No & 55 & 52 & 107 \\
Yes & 49 & 52 & 101 \\
\hline
\end{tabular}

Symmetric measures

\begin{tabular}{|c|c|c|}
\hline Nominal by nominal & Value & Approximate significance \\
\hline Phi &, 029 &, 677 \\
Cramer's V &, 029 &, 677 \\
\hline
\end{tabular}

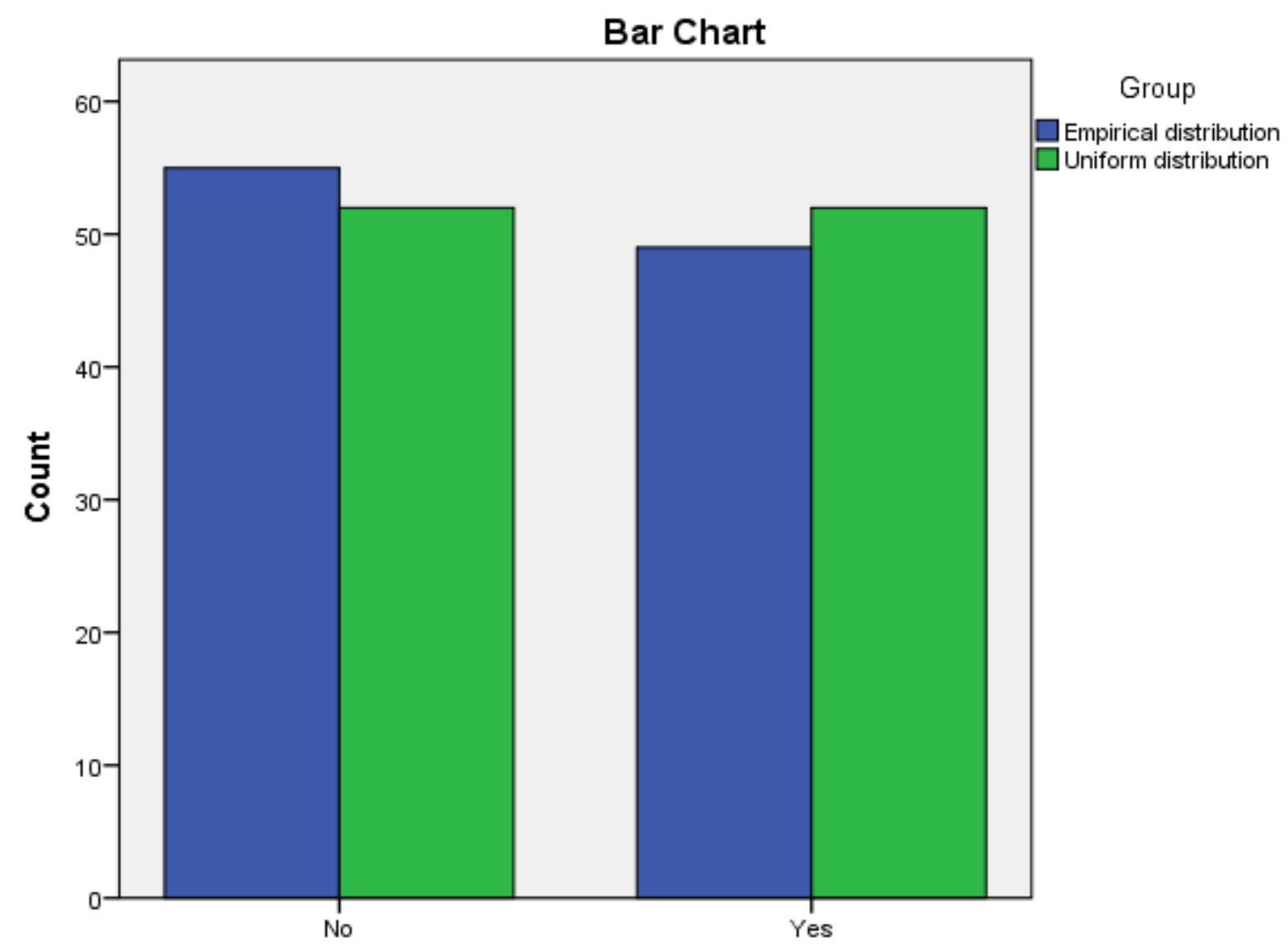

Figure 7. Answers to the question "I know that I will be able to remember it faster with the help of ICT" 


\begin{tabular}{|c|c|c|}
\hline \multirow{2}{*}{ Results of answers to the question } & \multicolumn{2}{|c|}{ Group } \\
\cline { 2 - 3 } & Empirical distribution & Uniform distribution \\
\hline No & 23 & 52 \\
Yes & 81 & 52 \\
\hline
\end{tabular}

Symmetric measures

\begin{tabular}{|c|c|c|}
\hline Nominal by nominal & Value & Approximate significance \\
\hline Phi &,- 290 &, 000 \\
Cramer's V &, 290 &, 000 \\
\hline
\end{tabular}

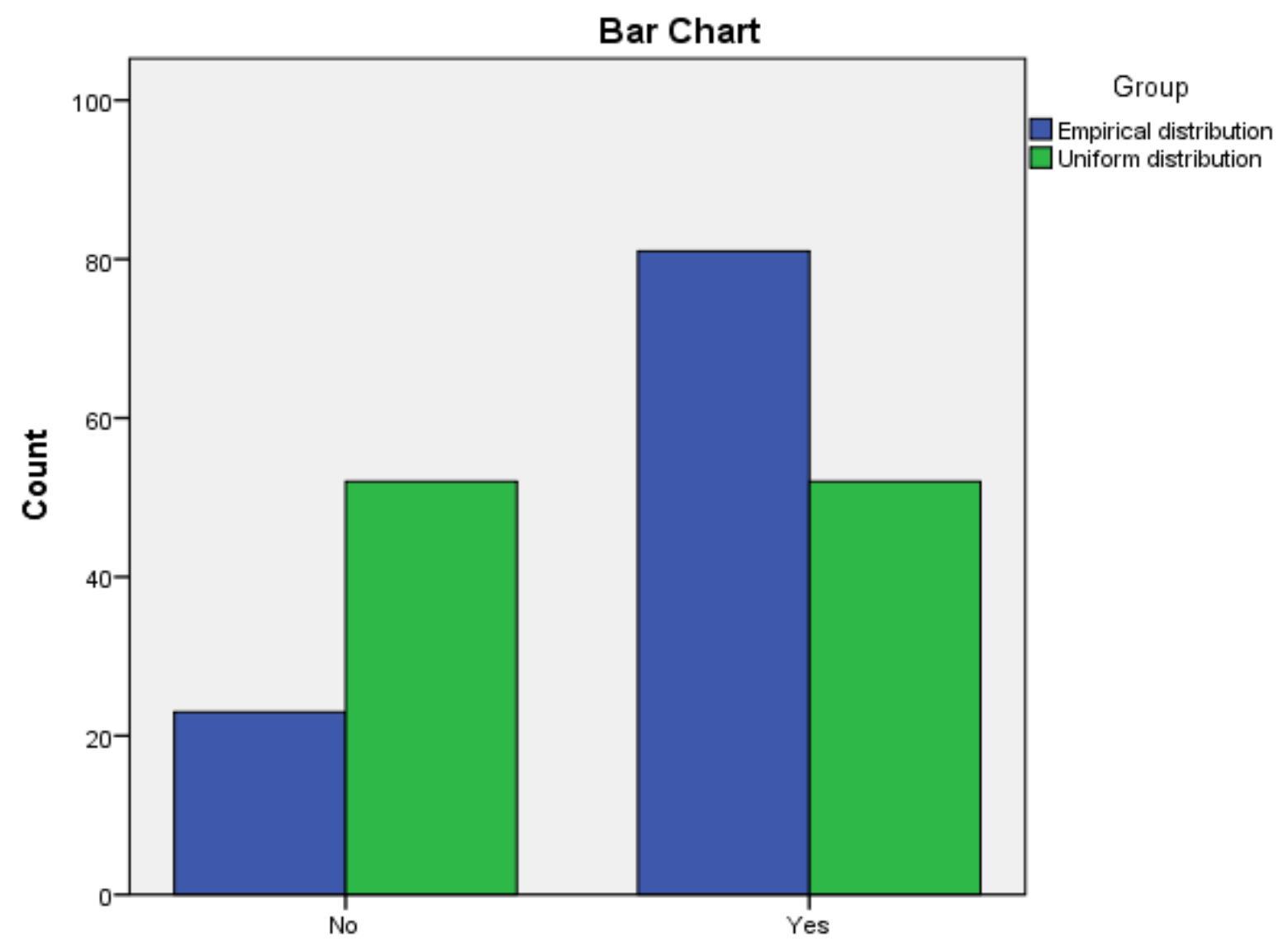

Figure 8. Answers to the question "I understand that I will be able to organize my time better with the help of ICT" 


\begin{tabular}{|c|c|c|c|}
\hline \multirow{2}{*}{ Answers to the question } & \multicolumn{2}{|c|}{ Group } & \multirow{2}{*}{ Total } \\
\cline { 2 - 4 } & Empirical distribution & Uniform distribution & \\
\hline No & 52 & 52 & 104 \\
Yes & 52 & 52 & 104 \\
\hline
\end{tabular}

Symmetric measures

\begin{tabular}{|c|c|c|}
\hline Nominal by nominal & Value & Approximate significance \\
\hline Phi &, 000 & 1,000 \\
Cramer's V &, 000 & 1,000 \\
\hline
\end{tabular}

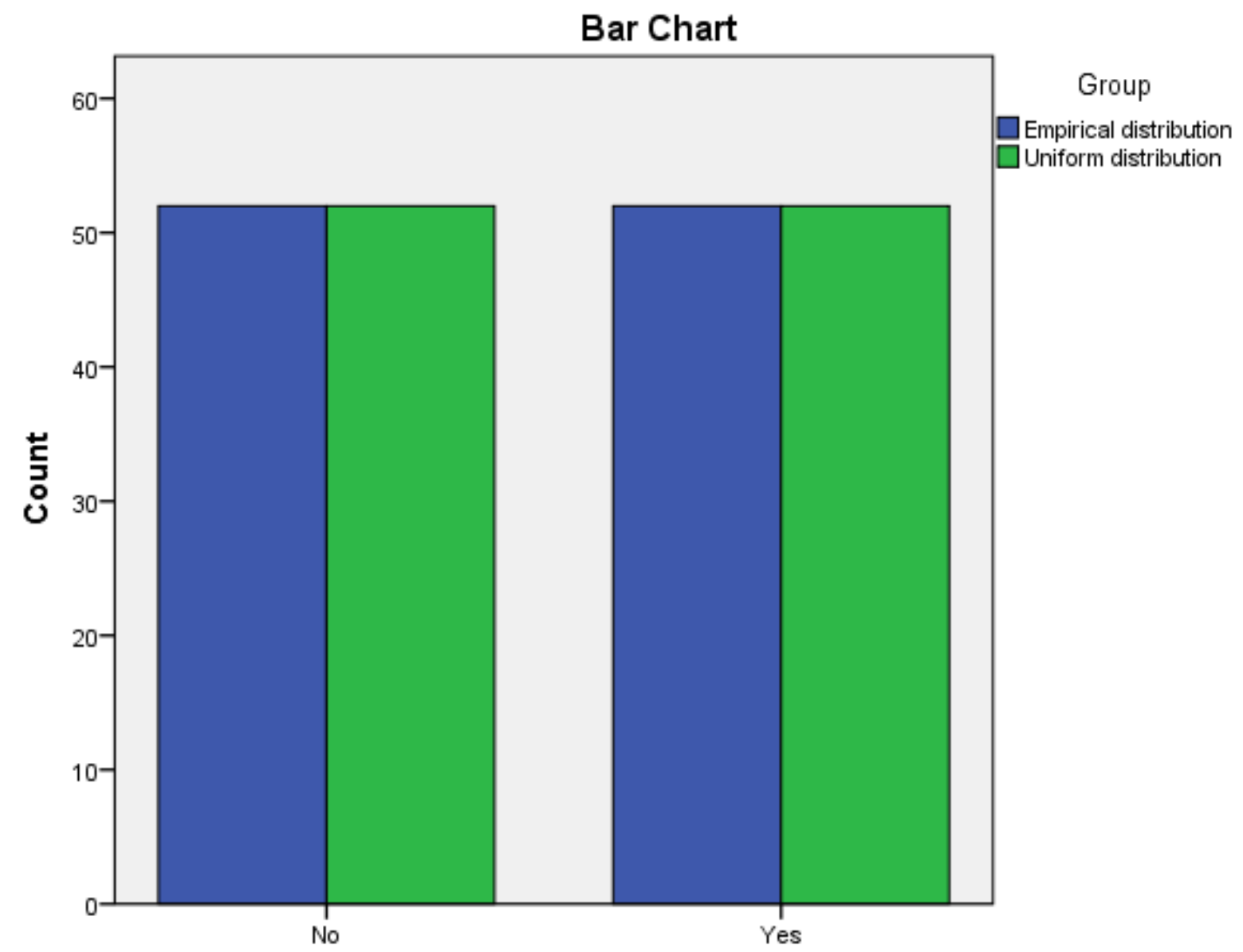

Figure 9. Answers to the question "I understand that I will be able to use my inclinations and abilities better to the ICT chosen" 


\begin{tabular}{|c|c|c|}
\hline \multirow{2}{*}{ Answers to the question } & \multicolumn{2}{|c|}{ Group } \\
\cline { 2 - 4 } & Empirical distribution & Uniform distribution \\
\hline No & 68 & 52 \\
Yes & 36 & 52 \\
\hline
\end{tabular}

Symmetric measures

\begin{tabular}{|c|c|c|}
\hline Nominal by nominal & Value & Approximate significance \\
\hline Phi &, 156 &, 025 \\
Cramer's V &, 156 &, 025 \\
\hline
\end{tabular}

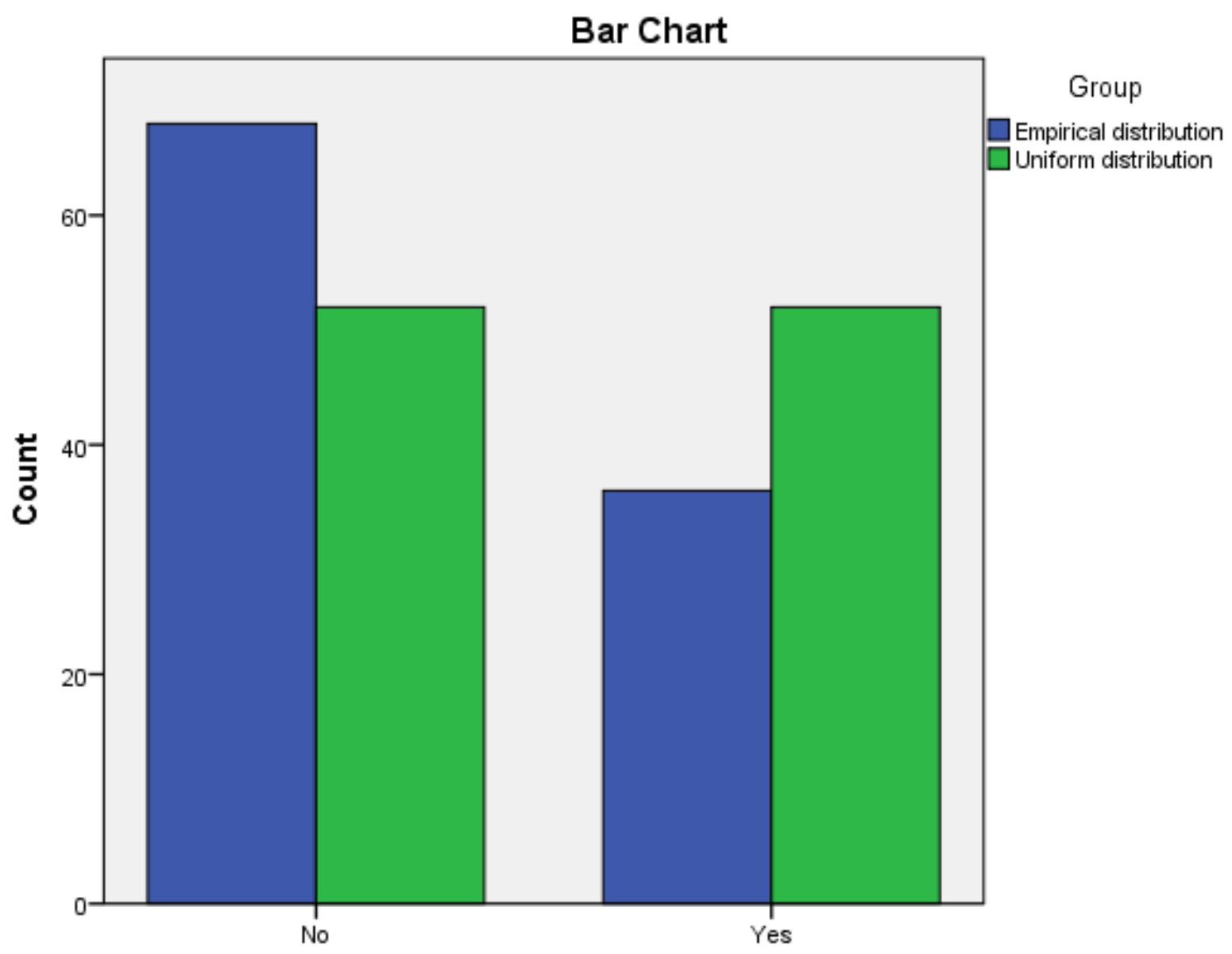

Figure 10. Answers to the question "I understand that I will be able to study well and to pass the exams for "4" and "5" with the help of ICT" 


\begin{tabular}{|c|c|c|c|}
\hline \multirow{2}{*}{ Answers to the question } & \multicolumn{2}{|c|}{ Group } & \multirow{2}{*}{ Total } \\
\cline { 2 - 4 } & Empirical distribution & Uniform distribution & 109 \\
\hline No & 57 & 52 & 99 \\
Yes & 47 & 52 & 99 \\
\hline
\end{tabular}

Symmetric measures

\begin{tabular}{|c|c|c|}
\hline Nominal by nominal & Value & Approximate significance \\
\hline Phi &, 048 &, 488 \\
Cramer's V &, 048 &, 488 \\
\hline
\end{tabular}

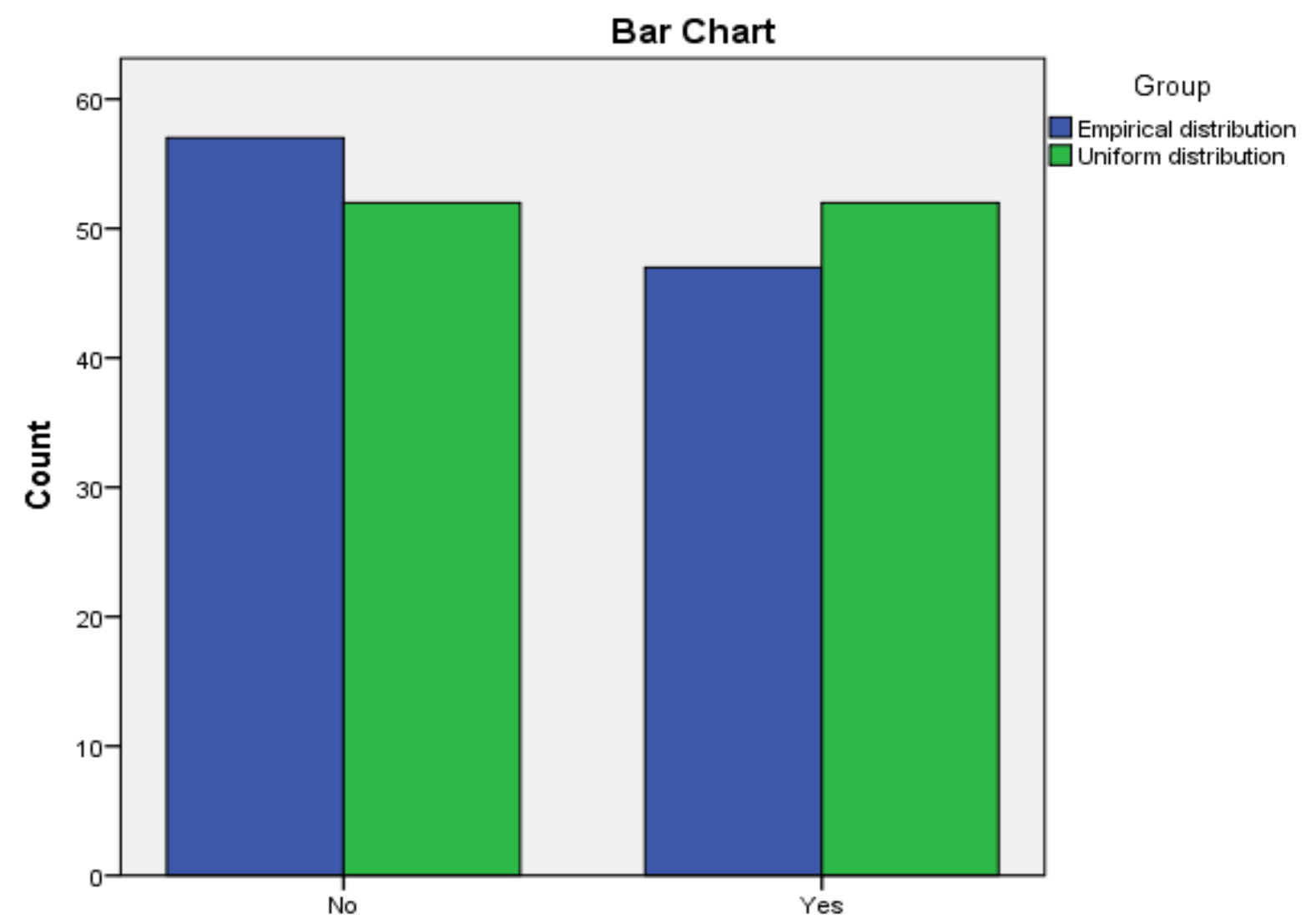

Figure 11. Answers to the question "I understand that I will be able to be ready for the lessons with the help of ICT" 


\begin{tabular}{|c|c|c|c|}
\hline \multirow{2}{*}{ Answers to the question } & \multicolumn{2}{|c|}{ Group } & \multirow{2}{*}{ Total } \\
\cline { 2 - 4 } & Empirical distribution & Uniform distribution & \\
\hline No & 38 & 52 & 90 \\
Yes & 66 & 52 & 118 \\
\hline
\end{tabular}

Symmetric measures

\begin{tabular}{|c|c|c|}
\hline Nominal by nominal & Value & Approximate significance \\
\hline Phi &,- 136 &, 050 \\
Cramer's V &, 136 &, 050 \\
\hline
\end{tabular}

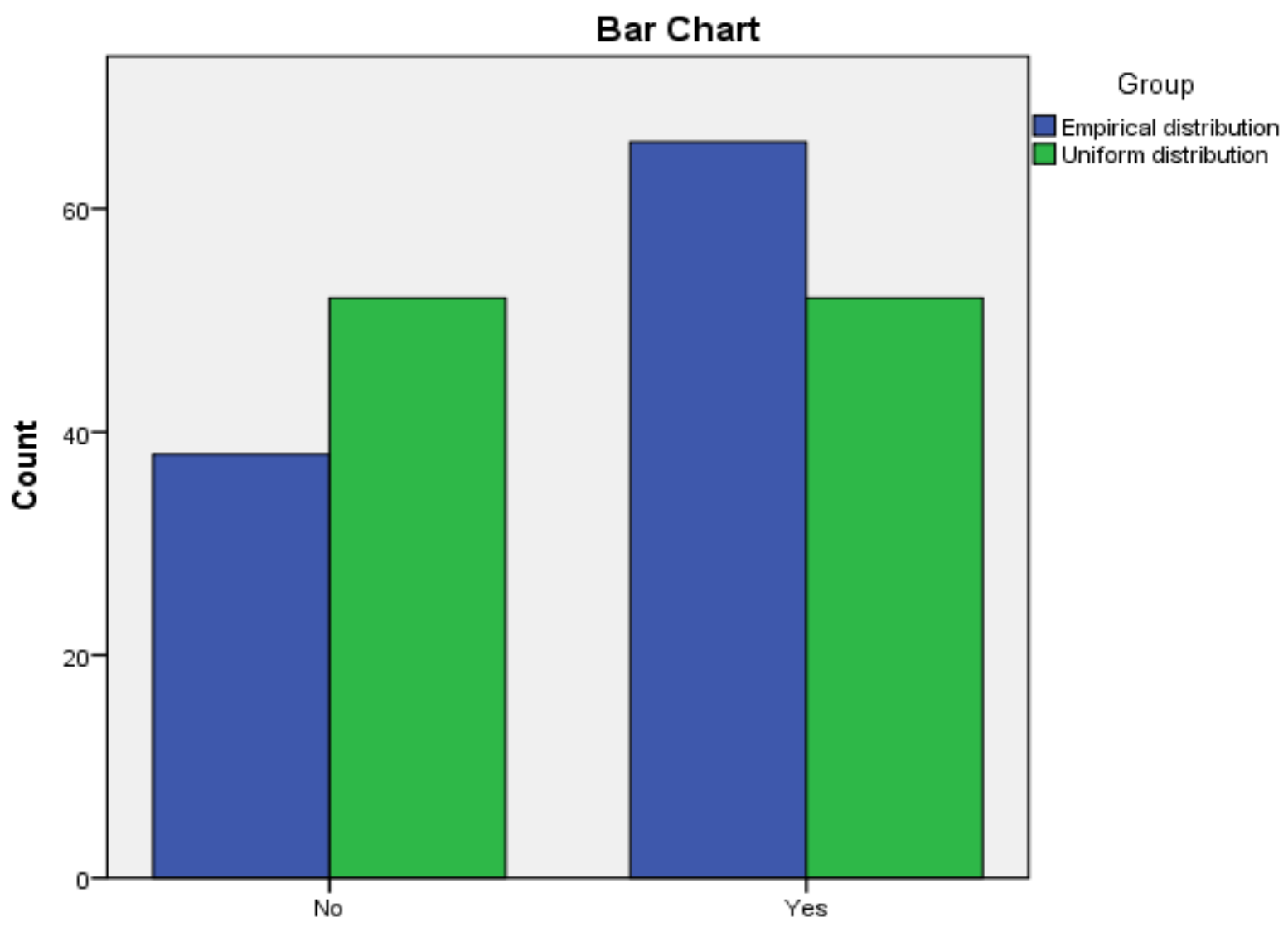

Figure 12. Answers to the question "I understand that I will be able to pay attention to the problems interesting for me with the help of ICT" 


\begin{tabular}{|c|c|c|c|}
\hline \multirow{2}{*}{ Answers to the question } & \multicolumn{2}{|c|}{ Group } & \multirow{2}{*}{ Total } \\
\cline { 2 - 4 } & Empirical distribution & Uniform distribution & \\
\hline No & 51 & 52 & 103 \\
Yes & 53 & 52 & 105 \\
\hline
\end{tabular}

Symmetric measures

\begin{tabular}{|c|c|c|}
\hline Nominal by nominal & Value & Approximate significance \\
\hline Phi &,- 010 &, 890 \\
Cramer's V &, 010 &, 890 \\
\hline
\end{tabular}

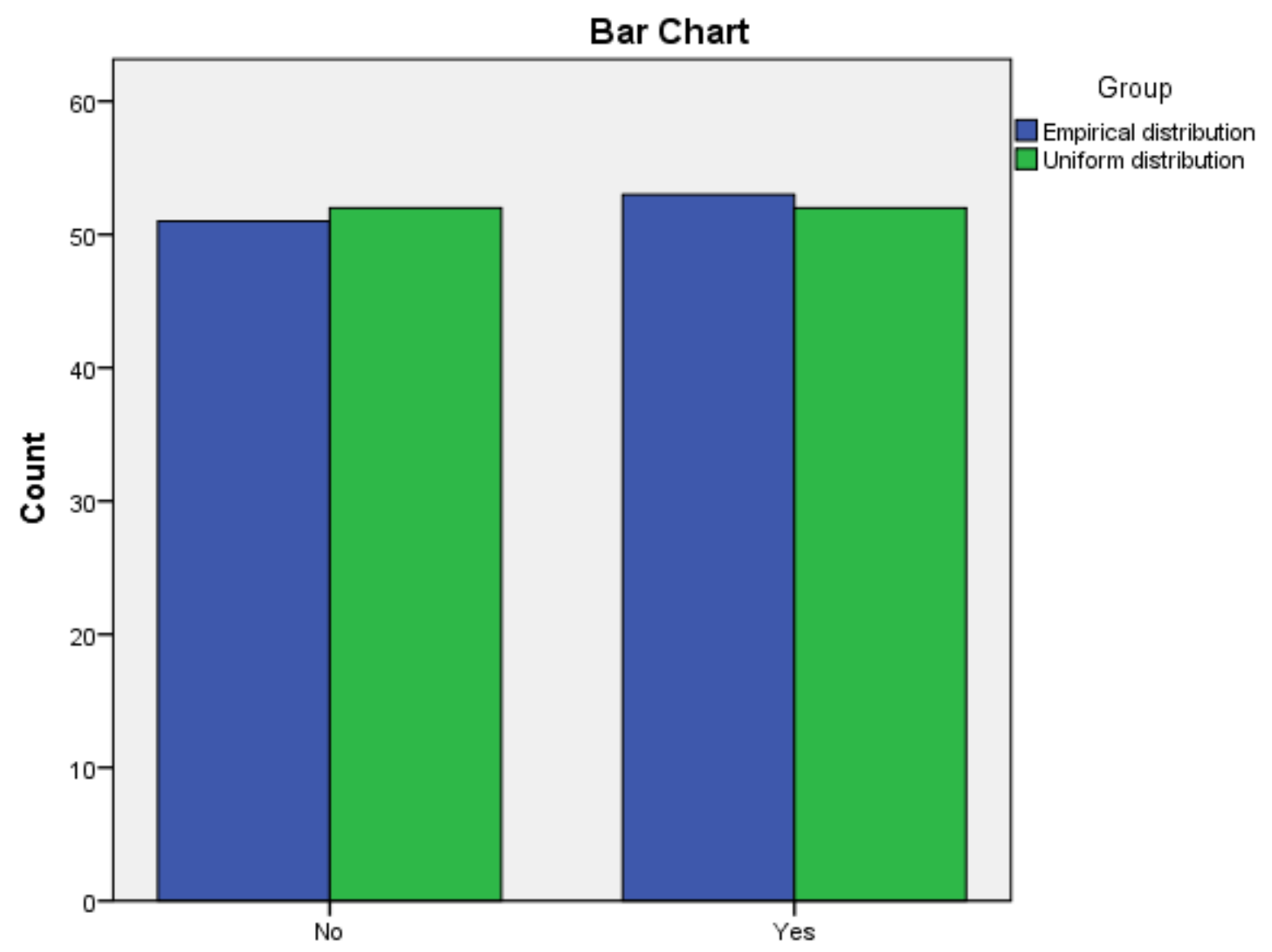

Figure 13. Answers to the question "I understand that I will be able to obtain more information with the help of ICT" 


\begin{tabular}{|c|c|c|c|}
\hline \multirow{2}{*}{ Answers to the question } & \multicolumn{2}{|c|}{ Group } & \multirow{2}{*}{ Total } \\
\cline { 2 - 4 } & Empirical distribution & Uniform distribution & \\
\hline No & 51 & 52 & 103 \\
Yes & 53 & 52 & 105 \\
\hline
\end{tabular}

Symmetric measures

\begin{tabular}{|c|c|c|}
\hline Nominal by nominal & Value & Approximate significance \\
\hline Phi &,- 010 &, 890 \\
Cramer's V &, 010 &, 890 \\
\hline
\end{tabular}

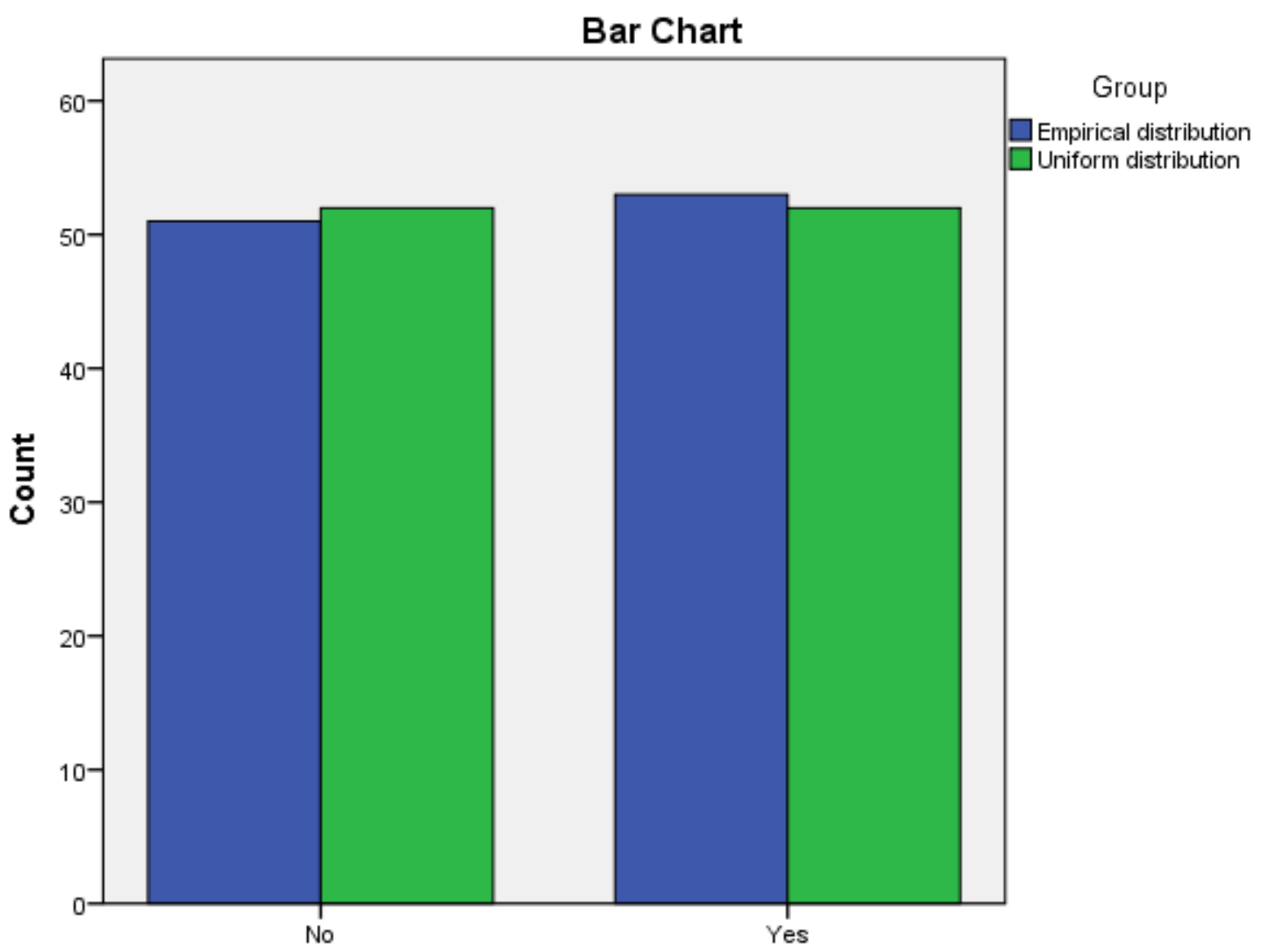

Figure 14. Answers to the question "I understand that I will be able to increase my marks with the help of ICT" 


\begin{tabular}{|c|c|c|c|}
\hline \multirow{2}{*}{ Answers to the question } & \multicolumn{2}{|c|}{ Group } & \multirow{2}{*}{ Total } \\
\cline { 2 - 4 } & Empirical distribution & Uniform distribution & \\
\hline No & 49 & 52 & 101 \\
Yes & 55 & 52 & 107 \\
\hline
\end{tabular}

Symmetric measures

\begin{tabular}{|c|c|c|}
\hline Nominal by nominal & Value & Approximate significance \\
\hline Phi &,- 029 &, 677 \\
Cramer's V &, 029 &, 677 \\
\hline
\end{tabular}

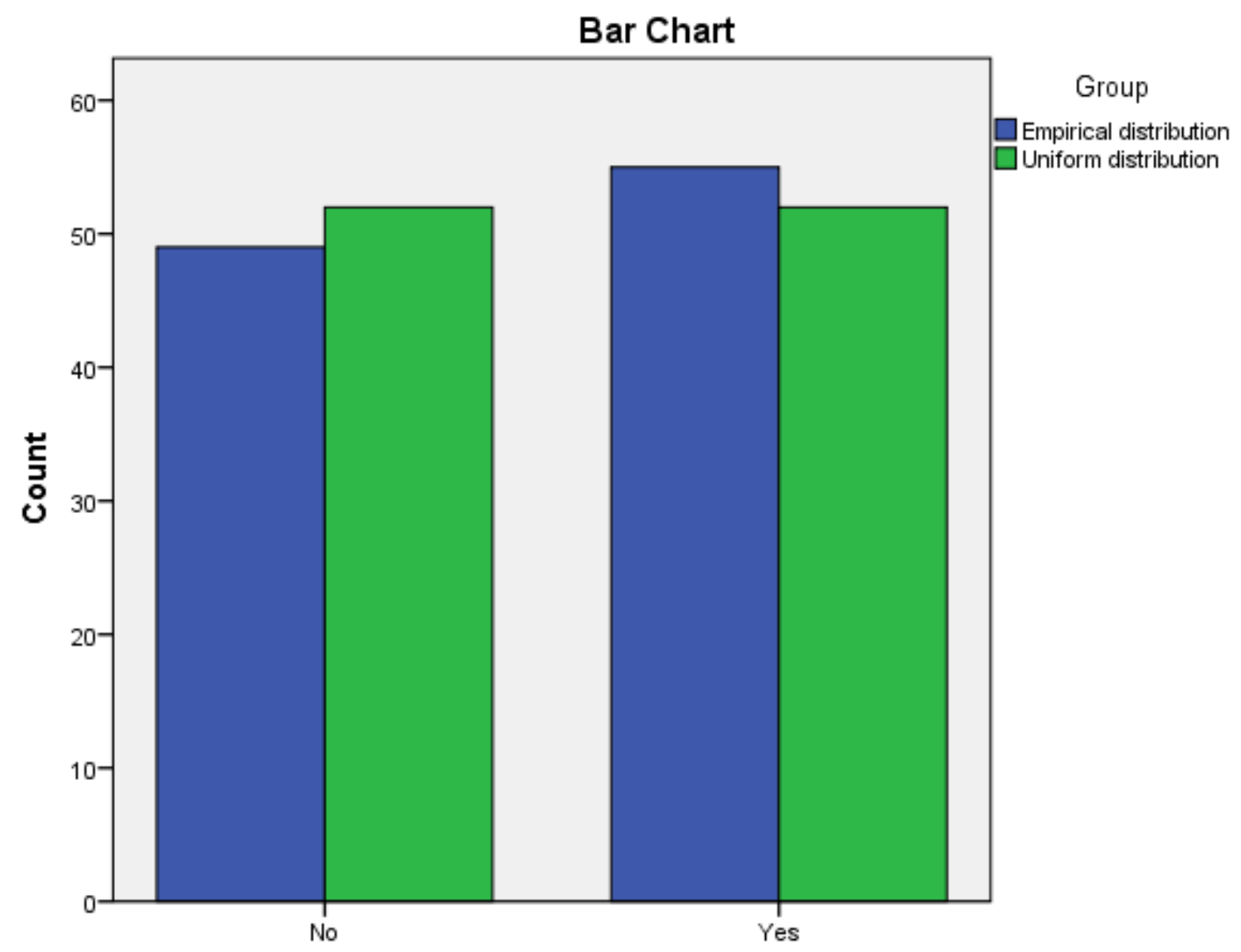

Figure 15. Answers to the question "I understand that I will be able to study the initial training program with the help of ICT" 


\begin{tabular}{|c|c|c|c|}
\hline \multirow{2}{*}{ Answers to the question } & \multicolumn{2}{|c|}{ Group } & \multirow{2}{*}{ Total } \\
\cline { 2 - 4 } & Empirical distribution & Uniform distribution & \\
\hline No & 47 & 52 & 99 \\
Yes & 57 & 52 & 109 \\
\hline
\end{tabular}

Symmetric measures

\begin{tabular}{|c|c|c|}
\hline Nominal by nominal & Value & Approximate significance \\
\hline Phi &,- 048 &, 488 \\
Cramer's V &, 048 &, 488 \\
\hline
\end{tabular}

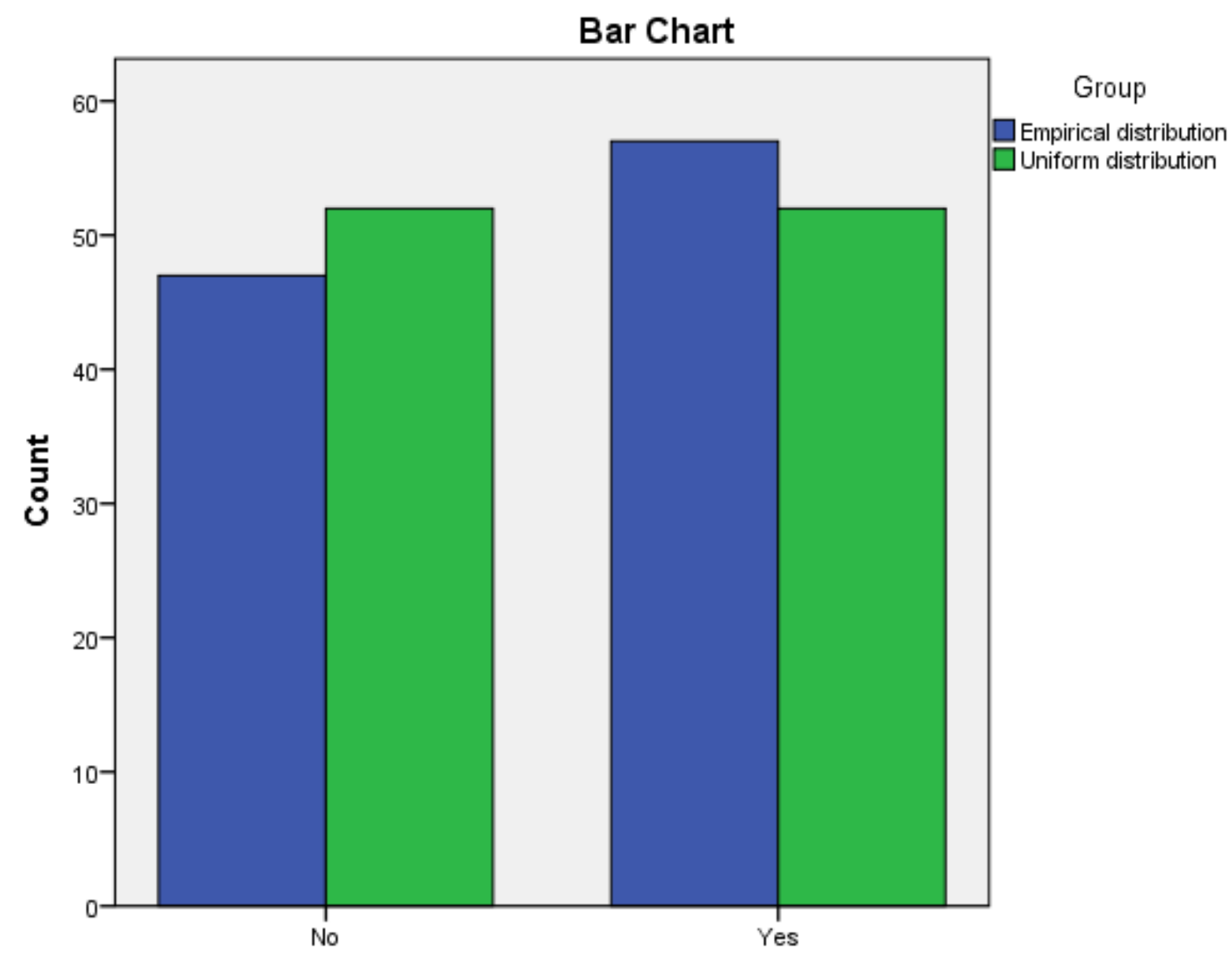

Figure 16. Answers to the question "I understand that I will be able to have better relations with teachers with the use of ICT" 


\begin{tabular}{|c|c|c|c|}
\hline \multirow{2}{*}{ Answers to the question } & \multicolumn{2}{|c|}{ Group } & \multirow{2}{*}{ Total } \\
\cline { 2 - 3 } & Empirical distribution & Uniform distribution & \\
\hline No & 50 & 52 & 102 \\
Yes & 54 & 52 & 106 \\
\hline
\end{tabular}

Symmetric measures

\begin{tabular}{|c|c|c|}
\hline Nominal by nominal & Value & Approximate significance \\
\hline Phi &,- 019 &, 781 \\
Cramer's V &, 019 &, 781 \\
\hline
\end{tabular}

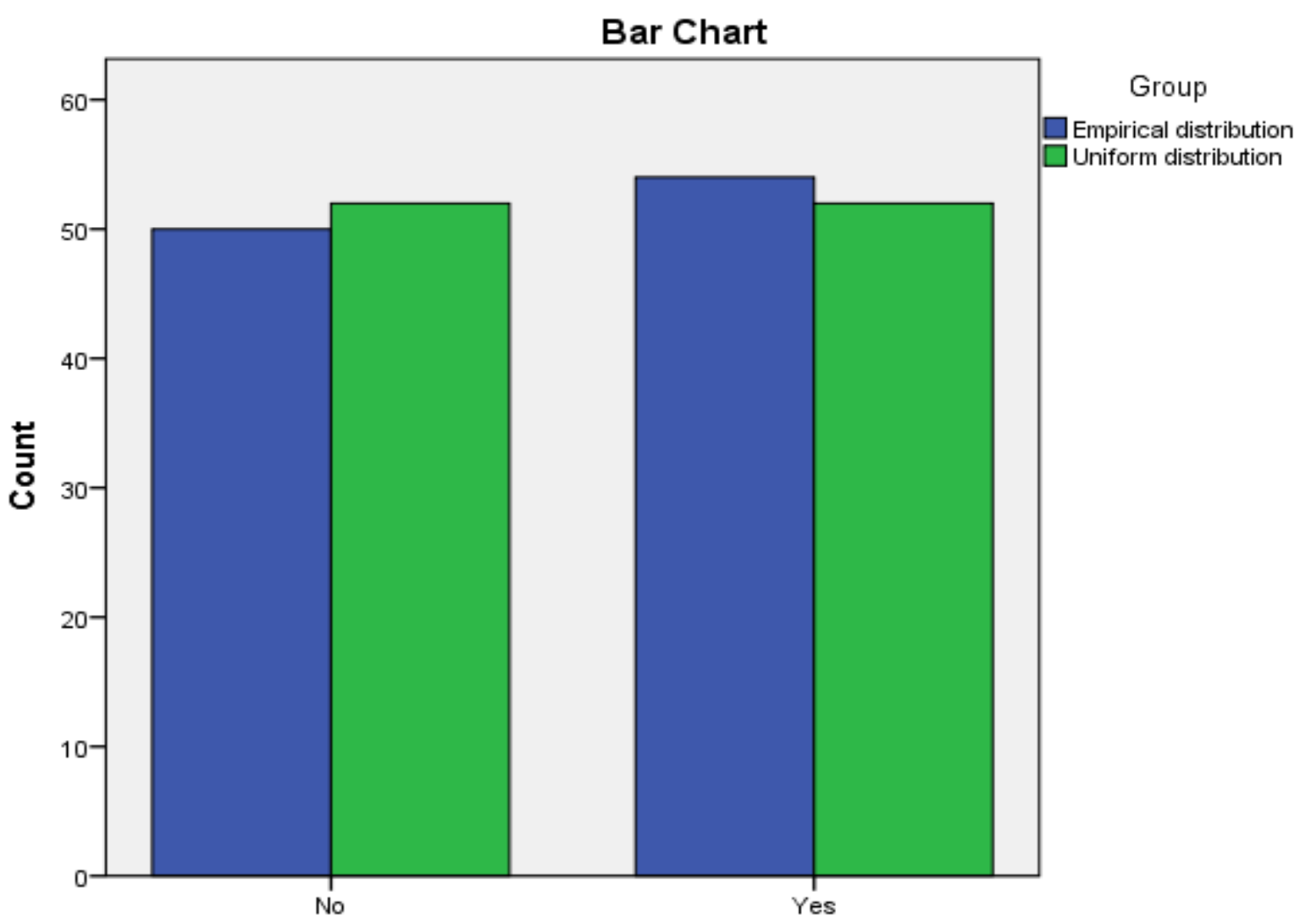

Figure 17. Answers to the question "I understand that I will be able to be appreciated well by parents with the help of ICT"

Consequently, the authors observed the significance level less than 0,05 only in the answers such as "I understand that I will be able to organize my time with the help of ICT" $(p=0,000)$, "I understand that I will be able to study well and to pass me exams on "4" and "5" with the help of ICT $(p=0,025)$, and "I understand that I will be able to pay attention to the problems interesting for me with the help of ICT" $(\mathrm{p}=0.05)$.

While answering to the question "I understand that I will be able to organize my time with the help of ICT", the number of "Yes" answers exceeded the answers under the even distribution - (81 answers). Thus, we could conclude that the students understand the ability to organize their time with the help of ICT.

While answering to the question "I understand that I will be able to study and pass the exams on " 4 " and " 5 " with the help of ICT", the number of answers exceeded the answers under the even distribution - (68 answers). However, the students did not believe ICT would help them to study well and pass the exams on "4" and "5".

While answering to the question "I understand that I will be able to pay attention to the problems interesting for me with the help of ICT", the number of answers exceeded the answers under the even distribution - (66 answers). This shows that the students understand that they will be able to pay attention to the problems interesting for them with the help of ICT.

\section{Discussion}

There are foreign studies indicating the positive effect of the use of the distance learning form or the opportunity of getting the same results from the full-day form (Neroni 
et al., 2019; Costa \& Claudia, 2019; Sublett, 2019; Grau-Valldosera, Minguillon \& Blasco-Moreno, 2019). For example, C.S. Cavanaugh (2001) studied the interactive distance learning efficiency in education through 19 experimental and quasi-experimental studies including 929 participants. He showed that the effect is more positive on the interactive programs of the distance learning forms, which combine an individual approach with the traditional learning program in the class. Moreover, F. Altinay et al. (2019) concluded that the distance learning form contributes to access to equal opportunities.

Based on the inner motivation theory, we studied not only the efficiency of the use of the distance learning form but also the motivation to education of 104 students using both the distance and full-day learning forms. In order to collect data, the authors created a blank, which consists of two parts: a blank for identification of the students' inner motivation and a blank for identification of the efficiency of the use of distance learning form.

Therefore, we used Kolmogorov-Smirnov test and distribution-free test to analyze the data of the first blank and identified that there is not a significant difference between motivation to education of students in the distance and full-day learning forms with regard to their gender $(p>0,05)$. The significance level was 0,574 , which was higher than 0.05 , meaning that there is no statistically significant difference between the groups. Perhaps, the most important motives in a full-day form are communicative, education, and cognitive factors, while professional and social motives are the most important factors in the distance learning form.

Then, we used Pearson's chi-squared test to analyze data of the second blank and identified the significance level lower than 0,05 only while answering to the questions such as "I understand that I will be able to organize my time better with the help of ICT" $(p=0,000)$, "I understand that I will be able to study and to pass the exams on "4" and " 5 " with the help of ICT" $(p=0,025)$, "I understand that I will be able to focus my attention on issues, which are interesting for me, with the help of ICT" IKT» $(p=0,05)$. It should be mentioned that the number of "Yes" answers to a question such as "I understand that I will be able to organize my time better with the help of ICT", exceeded the answers on even distribution (81 answer).

In fact, we not only examined possible efficiency of the use of the distance learning form but also the students' motivation to education. It is important that people understand their role in the process of availability, institutional support, technological infrastructure, students' support, the study-educational context, and the distance learning form program based on education and equity during their life.

\section{Conclusions}

It was found that the choice between traditional and ICT-based educational approaches to education seriously influenced the distribution of students' motivational values. In fact, students showed higher efficiency index while studying the law with the help of the distance learning form. However, the presence of students' motivation to education does not mean the presence of motivation to education in a full-day learning form at all. Moreover, a choice between the forms of education is the main reason for the need for the implementation of the distance learning form in the higher school of law.

The results of this research have practical values for consultations and development of training programs on the specialty "Law".

\section{Recommendations}

The authors offered to use the distance learning form in the legal sector not as an alternative but as a main part of an education program. One of the main reasons for the implementation of the distance learning form in the legal sector is to provide students with the access to different education in comparison with traditional methods, meaning that students may start their education from any place. In this way, they would also be provided with an opportunity to combine education methods. Therefore, we recommend the use of the distance learning form by students who need time for legal practice, or by those who cannot study with the help of a full-day form. It is notable that the results obtained from the distance learning form do not differ from the outputs of a full-day program.

\section{Appendix}

Every student was asked to answer on a 1-5 scale to the statements:

(a) on a full-day form

(b) on the distance learning from

The blank for determining inner motivation of the third-year students

1. I study because I like the job I chose. yes/no

2. To provide the success of the future job activity. yes/no

3. I want to become the specialist. yes/no

4. To give an answer to topical problems concerning future job activity. yes/no

5. I want to use the inclinations and abilities to the job I chose. yes/no

6. In order not to fall behind the friends. yes/no 
7. In order to work with people one has to have deep and comprehensive knowledge. yes/no

8. Because I want to be among the best students. yes/no

9. Because I want our learning group to be the best in the university. yes/no

10. To get acquainted with interesting people and communicate with them. yes/no

11. Because the knowledge obtained allows me to reach everything I want. yes/no

12. I have to graduate from the university in order not to allow my friends to change their opinion about me as about good person. yes/no

13. In order to avoid being punished for that I study bad. yes/no

14. I want to be respected by the learning group. yes/no

15. I don't want to fall behind my classmates as I don't want to be among them. yes/no

16. Because the level of my material situation depends on my education success. yes/no

17. To study well and to pass the exams on "4" and " 5 ". yes/no

18. I like studying. yes/no
19. Once entered the university, I have to graduate from it. yes/no

20. To be ready for the lessons. yes/no

21. To continue studying on further courses to give answers to specific learning questions. yes/no

22. To acquire deep and good knowledge. yes/no

23. Because I want to start scientific activity in the future. yes/no

24. Any knowledge will come in handy in the future job. yes/no

25. Because I want to do good to the society. yes/no

26. To be a highly-qualified man. yes/no

27. To learn new things and to do creativity. yes/no

28. To give answers to the problems of the society development and peoples' vital activity. yes/no

29. To be greatly respected by teachers. yes/no

30. To gain the parents' approval. yes/no

31. I study to do my duty to parents. yes/no

32. Because knowledge gives me confidence. yes/no

33. Because I want to get a diploma with good marks to get the advantage over others. yes/no

Table 1. The blank of the efficiency of the use of the distance learning form

\begin{tabular}{|c|c|c|c|}
\hline No. & Questions & Yes & No \\
\hline 1 & I understand that I will be able to study faster with the help of ICT. & & \\
\hline 2 & I understand I will be able to remember the program faster with the help of ICT. & & \\
\hline 3 & I understand that I will be able to organize my time with the help of ICT. & & \\
\hline 4 & I understand that I will be able to use the inclinations and abilities with the help of ICT. & & \\
\hline 5 & I understand that I will be able to study well and to pass the exams on "4" and " 5 " with the help of ICT. & & \\
\hline 6 & I understand that I will be able to be ready for the lessons with the help of ICT. & & \\
\hline 7 & I understand that I will be able to pay attention to the problems interesting for me with the help of ICT. & & \\
\hline 8 & I understand that I will be able to obtain more information with the help of ICT. & & \\
\hline 9 & I understand that I will be able to improve my marks with the help of ICT. & & \\
\hline 10 & I understand that I will be able to study the learning program with the help of ICT. & & \\
\hline 11 & I understand that I will be able to establish good relations to teachers with the help of ICT. & & \\
\hline 12 & I understand that I will be able to be appreciated well by my parents with the help of ICT. & & \\
\hline
\end{tabular}




\section{REFERENCES}

[1] Ali, A.M., Sahbi, A. \& Ayari, A. (2012). Effects of use of technology on students' motivation, Journal of teaching and education, 1, 407-412.

[2] Altinay, F., Altinay, M, Dagli, G. \& Altinay, Z. (2019). A study of knowledge management systems processes and technology in open and distance education institutions in higher education. International journal of information and learning technology, 36(4), 314-321.

[3] Badmayeva, N.G. (2004). Vliyaniye motivatsyonnogo factora na razvitiye umstvennykh sposobnostei. Ulan-Ude: Slovo.

[4] Cavanaugh, C.S. (2001). The effectiveness of interactive distance education technologies in K-12 learning: a meta-analysis. International Jl. of Educational Telecommunications, 7(1), 73-88.

[5] Costa, C. \& Claudia, A. (2019). Students in distance education contexts. Variables linked to academic achievement. RIED. Revista Iberoamericana de Educación a Distancia, 22(2), 203-223.

[6] El-Seoud, S.A., Taj-Eddin, I., Seddiek, N., Mohamed, M. (2014). E-Learning and Students' Motivation: A Research Study on the Effect of E-Learning on Higher Education. International Journal of Emerging Technologies in Learning (iJET), 9(4), 20-26.

[7] Francis, J. (2017). The Effects of technology on student motivation and engagement in classroom-based learning. URL: http://dune.une.edu/theses/121

[8] Grau-Valldosera, J., Minguillon, J. \& Blasco-Moreno, A. (2019). Returning after taking a break in online distance higher education: from intention to effective re-enrollment. Interactive Learning Environments, 27(3), 307-323.

[9] Hartnett, M., George, A. \& Dron, J. (2011). Examining Motivation in Online Distance Learning Environments: Complex, Multifaceted, and Situation-Dependent. Research Articles, 12(6), 20-38

[10] Lucky, A., Branham, M. \& Atchison, R. (2019). Collection-Based Education by Distance and Face to Face: Learning Outcomes and Academic Dishonesty. Journal of Science Education and Technology, 28(4), 414-428. https://doi.org/10.1007/s10956-019-9770-8

[11] Mbaeze, I.C., Elochukwu, U. \& Choima A. (2010). The Influence of Information and Communication Technologies on Students' Academic Performance. Journal of Information Technology Impact, 10(3), 129-136.

[12] Muilenburg, L.Y., \& Berge, Z.L. (2005). Student barriers to online learning: A factor analytic study. Distance Education, 26(1), 29-48. URL: https://doi: 10.1080/015879 10500081269

[13] Nakaz Ministerstva osvity ta nauky vid 10.10.2018. (2018). Pro provedennya eksperimentu vseukrainskogo rivya za temou "Organizatsiya profesiinogo navchnnya uchnivskoi molodi i doroslykh yaki prozhyvayut na tymchasovo okupovani terrytorii. URL: https://mon.gov.ua/ua/npa/proprovedennya-eksperimentu-vseukrayinskogo-rivnya-za-te moyu-organizaciya-profesijnogo-navchannya-uchnivskoyimolodi-j-doroslih-yaki-prozhivayut-na-timchasovo-okupo vanij-teritoriyi-ta-v-naselenih-punktah-na-liniyi-zitknenny a

[14] Neroni, J., Meijs, C., Gijselaers, H.J.M. \& de Groot R.H.M. (2019). Learning strategies and academic performance in distance education. Learning and Individual Differences, $73,1-7$.

[15] Pro dystantsiine navchnnya. (2013). Nakaz MON Ukrainy vid 25.04.2013 № 466. Ofitsiinyi visnyk Ukrainy. № 36. Art. 202.

[16] Pro osvitu. (2017). Zakon Ukrainy vid 05.09.2017 № 2145-VIII. Vidomosti Verkhovnoi Rady Ukrainy и 2017. № 38-39. Art. 5.

[17] Pro vyshu osvitu. (2014). Zakon Ukrainy vid П 01.07.2014 № 1556-VI. Vidomosti Verkhovnoi Rady Ukrainy, №37-38. Art. 2716.

[18] Radovan, M. (2011). The relation between distance students' motivation, their use of learning strategies, and academic success. (TOJET) The Turkish online journal of educational technology, 10(1), 216-222.

[19] Sublett, C. (2019). Examining distance education Coursetaking and Time-to-Completion among Community College Students. Community College Journal of Research and Practice, 43(3), 201-215.

[20] White, R.W. (1959). Motivation reconsidered: The concept of competence. Psychological Review, 66, 297-333.

[21] Woodworth, R. (1950). Experimentalnaya Psichologiya. Moscow: Izdatelstvo inostrannoi literatury.

[22] Wu, D.D. (2015). Online learning in postsecondary education: a review of the empirical literature. URL: https://doi. org/10.18665/sr.221027

[23] Zaccone, M. \& Pedrini, M. (2019). The effects of intrinsic and extrinsic motivation on students learning effectiveness. Exploring the moderating role of gender. International Journal of Educational Management, 33(6), 1381-1394. 